\title{
Cytoskeletal Links of Neuronal Acetylcholine Receptors Containing $\alpha 7$ Subunits
}

\author{
Richard D. Shoop, ${ }^{1}$ Naoko Yamada, ${ }^{2}$ and Darwin K. Berg ${ }^{1}$ \\ ${ }^{1}$ Department of Biology and ${ }^{2}$ National Center for Microscopy and Imaging Research, University of California, San Diego, \\ La Jolla, California 92093-0357
}

Nicotinic acetylcholine receptors serve a variety of signaling functions in the nervous system depending on cellular location, but little is known about mechanisms responsible for tethering them at specific sites. Among the most interesting are receptors containing the $\alpha 7$ gene product, because of their abundance and high relative permeability to calcium. On chick ciliary ganglion neurons $\alpha 7$-containing receptors are highly concentrated on somatic spines folded into discrete patches on the cell. We show that the spines contain filamentous actin and drebrin. After cell dissociation, the actin slowly redistributes, the spines retract, and the $\alpha 7$-containing receptors disperse and are subsequently lost from the surface. Latrunculin $A, a$ drug that depolymerizes filamentous actin, accelerates receptor dispersal, whereas jasplikinolide, a drug that stabilizes the actin cytoskeleton, preserves large receptor clusters and prevents receptor loss from the surface. The receptors are resis-

A critical feature of circuit formation in the nervous system is the proper positioning of neurotransmitter receptors. This is particularly important for ionotropic receptors permeable to calcium because the resulting calcium influx can have pleiotropic effects if not restricted in location. The best-studied example is that of NMDA receptors that are often concentrated in postsynaptic densities on dendritic spines (Harris and Kater, 1994). In the hippocampus, activation of NMDA receptors can produce calcium-dependent modulation of synaptic function, including long-term potentiation and depression (Malenka and Nicoll, 1999). Confining the receptors to the spine spatially limits the spread of calcium influx and the resulting modulation (Muller and Connor, 1991; Yuste and Denk, 1995; Engert and Bonhoeffer, 1997; Mainen et al., 1999) and reduces the risk of nonspecific destructive effects such as excitotoxicity (Choi, 1992).

Complex mechanisms can be devoted to localizing and controlling calcium-permeable ionotropic receptors. Again this is best documented for NMDA receptors where an elaborate molecular scaffold clusters machinery required for signal transduction and receptor regulation. Postsynaptic density-95 (PSD-95) protein provides the backbone for tethering numerous regulatory com-

Received Feb. 1, 2000; revised March 20, 2000; accepted March 24, 2000.

This work was supported by National Institutes of Health Grants NS 12601, NS 35469, and RR 04050 and by Tobacco-Related Disease Research Program Grant 6RT-0050. We thank Drs. Maryann Martone and Mark H. Ellisman (University of California, San Diego, La Jolla, CA) for helpful advice and Dr. Jon Lindstrom (University of Pennsylvania, Philadelphia, PA) for mAb 35.

Correspondence should be addressed to Dr. Darwin K. Berg, Department of Biology, 0357, University of California, San Diego, 9500 Gilman Drive, La Jolla, CA 92093-0357. E-mail: dberg@ucsd.edu.

Copyright (C) 2000 Society for Neuroscience 0270-6474/00/204021-09\$15.00/0 tant to extraction by nonionic detergent even after latrunculin A treatment. Other, less abundant, nicotinic receptors on the neurons are readily solubilized by the detergent even though these receptors are located in part on the spines. The results demonstrate that the actin cytoskeleton is important for retaining receptor-rich spines and indicate that additional cytoskeletal elements or molecular interactions specific for $\alpha 7$ containing receptors influence their fate in the membrane. The cytoskeletal elements involved are not dependent on the architecture of the postsynaptic density because $\alpha 7$-containing receptors are excluded from such sites on ciliary ganglion neurons.

Key words: nicotinic; acetylcholine; $\alpha 7$; ciliary ganglion; spines; cytoskeleton; receptor; neuronal; synaptic; calyx; cholinergic

ponents close to the receptor via PDZ domains and may participate in clustering the receptors (Kornau et al., 1995; Brenman et al., 1996; Hsueh et al., 1997). Actin filaments, necessary for sustaining spine structure, have a dual effect on NMDA receptors; they prevent relocation of the receptors (Allison et al., 1998) and influence receptor function via a calcium-sensitive, calmodulin-blocked $\alpha$-actinin link (Rosenmund and Westbrook, 1993; Wyszynski et al., 1997; Krupp et al., 1999).

Nicotinic acetylcholine receptors containing the $\alpha 7$ gene product ( $\alpha 7$-nAChRs) are widely distributed in the nervous system (Couturier et al., 1990; Schoepfer et al., 1990; Anand et al., 1993; Conroy and Berg, 1998) and have a high relative permeability to calcium (Bertrand et al., 1993; Seguela et al., 1993). On chick ciliary neurons the receptors are concentrated on somatic spines folded into discrete clumps on the cells (Shoop et al., 1999). Synaptic stimulation of the receptors elicits large, rapidly decaying responses (Zhang et al., 1996; Ullian et al., 1997) that promote reliable, synchronous firing through the ganglion during development (Chang and Berg, 1999). Recent studies have shown that receptor function is augmented by extracellular calcium acting at extracellular sites (Liu and Berg, 1999a). More important, calcium influx through the receptors permits calmodulin to regulate opposing actions of calcineurin and CaM kinase II on activity-dependent rundown of the $\alpha 7-\mathrm{nAChR}$ response (Liu and Berg, 1999b). The rate of rundown is influenced by the state of the actin cytoskeleton and does not extend to a less abundant class of nicotinic receptors expressed by the neurons, namely, those composed of $\alpha 3, \beta 4, \alpha 5$, and sometimes $\beta 2$ subunits $\left(\alpha 3^{*}\right.$-nAChRs).

The present experiments were undertaken to determine how 
the cytoskeleton influences the distribution of $\alpha 7$-nAChRs on ciliary ganglion neurons. The results show that collapse of actin filaments causes retraction of the somatic spines and dispersal of the receptors into microclusters. The receptors remain resistant, however, to detergent extraction, suggesting the involvement of yet other protein-protein interactions tethering $\alpha 7$-nAChRs.

\section{MATERIALS AND METHODS}

Cell cultures. Ciliary ganglia were dissected from embryonic day 15 (E15) chicks, dissociated into a cell suspension, and maintained in culture as described previously (Nishi and Berg, 1981; Zhang et al., 1994). For imaging experiments the cells were plated onto glass coverslips coated with polylysine and fibronectin; for binding experiments the cells were plated in plastic dishes coated with polylysine. Culture medium contained $10 \%(\mathrm{v} / \mathrm{v})$ heat-inactivated horse serum and 3\% (v/v) chick embryonic eye extract as described previously (Nishi and Berg, 1981). The cells were allowed to settle at least $20 \mathrm{~min}$ at $37^{\circ} \mathrm{C}$ for proper attachment before an experiment was initiated and then were maintained $4-24 \mathrm{hr}$ at $37^{\circ} \mathrm{C}$ in a $95 \%$ air $/ 5 \% \mathrm{CO}_{2}$ atmosphere. Drug treatments included latrunculin A (Molecular Probes, Eugene, OR) or jasplikinolide (Molecular Probes) being added to the culture medium from stock solutions (2 $\mathrm{mg} / \mathrm{ml}$ in DMSO) to a final concentration of $4 \mu \mathrm{g} / \mathrm{ml}$ for $4-24 \mathrm{hr}$.

Confocal fluorescence microscopy. Cells on glass coverslips were incubated with Alexa488-conjugated $\alpha$-bungarotoxin ( $\alpha$ Bgt; 1:500 dilution; Molecular Probes) for $20 \mathrm{~min}$ at $37^{\circ} \mathrm{C}$ to label $\alpha 7$-nAChRs and then washed three times in culture medium to remove unbound toxin, fixed in

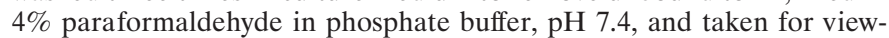
ing. In some experiments $\alpha 3^{*}$-nAChRs were labeled by incubating for 30 min at $37^{\circ} \mathrm{C}$ with the monoclonal antibody (mAb) 35 (1:1000 dilution) that recognizes the chicken $\alpha 1, \alpha 3$, and $\alpha 5$ subunits (Conroy and Berg, 1995); bound mAb was detected by following with indocarbocyanine (Cy3)-conjugated secondary antibodies (Jackson ImmunoResearch, West Grove, PA) and appropriate rinsing. To label filamentous actin with phalloidin or to label the actin-associated protein drebrin with an antidrebrin mAb (Medical and Biological Laboratories, Nagota, Japan), the cells were fixed, permeabilized by incubating for $20 \mathrm{~min}$ with $0.1 \%(\mathrm{w} / \mathrm{v})$ Triton X-100 in PBS $\left(0.15 \mathrm{M} \mathrm{NaCl}\right.$ and $\left.0.01 \mathrm{M} \mathrm{Na}_{2} \mathrm{HPO}_{4}, \mathrm{pH} 7.4\right)$ containing $5 \%(\mathrm{v} / \mathrm{v})$ normal donkey serum, and then incubated either 45 min in a 1:1000 dilution of rhodamine-conjugated phalloidin (Molecular Probes) or $1 \mathrm{hr}$ in a 1:1000 dilution of anti-drebrin mAb followed by Cy3-conjugated secondary antibody (Jackson ImmunoResearch). After rinsing, the cells were taken for viewing.

Fluorescence imaging was performed with a Bio-Rad MC1024 confocal microscope (Hercules, CA) with a $63 \times, 1.4$ numerical aperture objective lens. Optical sections were taken at $0.75 \mu \mathrm{m}$ intervals through the neuron, and the final volume was assembled digitally using Lasersharp software (Bio-Rad). A final projection was reconstructed from this volume using NIH Image Software (Bethesda, MD).

Electron microscopy. Immunogold labeling of $\alpha 7$-nAChRs was examined with electron microscopy using procedures described previously (Shoop et al., 1999). Briefly, dissociated neurons on glass coverslips were incubated for $1 \mathrm{hr}$ at $4^{\circ} \mathrm{C}$ in culture medium containing $10 \mathrm{~mm}$ HEPES, $\mathrm{pH} 7.4$, and $0.5 \mu \mathrm{M}$ biotinylated $\alpha$ Bgt. After five rinses with medium lacking $\alpha \mathrm{Bgt}$, the cells were fixed in $2 \%$ paraformaldehyde plus $2 \%$ glutaraldehyde in cacodylate buffer, $\mathrm{pH} \mathrm{7.4,} \mathrm{for} 20 \mathrm{~min}$ at room temperature. The cells were then incubated $45 \mathrm{~min}$ in PBS containing a 1:200 dilution of mouse anti-biotin mAb (Jackson ImmunoResearch), rinsed five times in PBS, and then incubated $45 \mathrm{~min}$ in PBS with donkey anti-mouse $\mathrm{mAb}$ conjugated to $10 \mathrm{~nm}$ immunogold (1:50 dilution; Amersham, Arlington Heights, IL) in PBS with 5\% (v/v) normal donkey serum. The samples were then rinsed extensively in $0.1 \mathrm{M}$ sodium cacodylate buffer, $\mathrm{pH} 7.4$, and treated for 30 min with $2 \%$ osmium tetroxide in $0.1 \mathrm{M}$ sodium cacodylate. The cells were counterstained with uranyl acetate, dehydrated in an ethanol series, and infiltrated with Durcupan ACM resin (Electron Microscopy Sciences, Fort Washington, PA). After polymerization for $24 \mathrm{hr}$ at $60^{\circ} \mathrm{C}$, the material was sectioned into $80-\mathrm{nm}$ thick sections that were viewed using a JOEL 100CX electron microscope.

${ }^{125} \mathrm{I}-\alpha B g t$ binding and detergent extraction. To quantify $\alpha 7-\mathrm{nAChRs}$ on the cell surface, cells were incubated for $20 \mathrm{~min}$ at $37^{\circ} \mathrm{C}$ with $10 \mathrm{nM}$ ${ }^{125} \mathrm{I}-\alpha \mathrm{Bgt} ; 1 \mu \mathrm{M}$ unlabeled $\alpha \mathrm{Bgt}$ was included in some samples to determine nonspecific labeling. For comparison, $\alpha 3^{*}$-nAChRs were labeled in separate cultures with $\left[{ }^{3} \mathrm{H}\right]$ epibatidine; in this case $2 \mathrm{~mm}$ nicotine was included to determine nonspecific binding. In some cases $\alpha 3^{*}$-nAChRs were labeled with ${ }^{125} \mathrm{I}-\mathrm{mAb} 35$; an excess of unlabeled mAb 35 was used to determine nonspecific binding. After rinsing three times with PBS, the cells were scraped in $1 \mathrm{~N} \mathrm{NaOH}$ and either taken for gamma counting in the case of ${ }^{125} \mathrm{I}$ samples or diluted in $5 \mathrm{ml}$ of Ecoscint $\mathrm{H}$ (National Diagnostics, Atlanta, GA) for ${ }^{3} \mathrm{H}$ samples and taken for scintillation counting. Binding was normalized for the number of cells present before scraping; this imposed a correction of $\leq 20 \%$ for latrunculin A-treated cultures.

The resistance of $\alpha 7$-nAChRs to detergent extraction was assessed by incubating labeled cells in a solution containing $0.3 \mathrm{M}$ sucrose, $0.1 \mathrm{M} \mathrm{KCl}$, $2.5 \mathrm{mM} \mathrm{MgCl}_{2}, 1 \mathrm{mM} \mathrm{CaCl}_{2}$, and $10 \mathrm{~mm}$ PIPES, pH 6.8, on ice. Triton $\mathrm{X}-100$ was diluted into the solution at a final concentration of $1 \%(\mathrm{w} / \mathrm{v})$ and incubated on the cells for $10 \mathrm{~min}$ on ice before removing (extract) and rinsing with solution lacking detergent (rinse) (Phillips et al., 1993). The extract and rinse fractions were then pooled and labeled the "soluble" fraction and counted for radioactivity as above. The material remaining attached to the culture substratum was scraped in $1 \mathrm{~N} \mathrm{NaOH}$ and labeled the "insoluble" fraction and counted similarly. Unless otherwise indicated, results are expressed as the mean \pm SEM and were evaluated for significance using either the paired or unpaired $t$ test as appropriate.

Materials. White Leghorn chick embryos were obtained locally and maintained at $37^{\circ} \mathrm{C}$ in a humidified incubator. mAb 35 was kindly provided by Dr. Jon Lindstrom (University of Pennsylvania, Philadelphia, PA). Both mAb 35 and $\alpha$ Bgt (Molecular Probes) were radioiodinated using chloramine $\mathrm{T}$ and had final specific activities of 113 and 2500 $\mathrm{cpm} / \mathrm{fmol}$, respectively. $\left[{ }^{3} \mathrm{H}\right]$ Epibatidine was a gift from DuPont NEN (Boston, MA). All other reagents were purchased from Sigma (St. Louis, MO) unless otherwise indicated.

\section{RESULTS \\ Spontaneous codispersal of actin filaments and $\alpha 7-\mathrm{nAChRs}$}

When chick ciliary ganglion neurons are first dissociated, they retain the mats of folded somatic spines seen in vivo, and the spines initially retain their complement of $\alpha 7$-nAChRs (Shoop et al., 1999). The spines are rich in filamentous action (F-actin) and the actin-associated protein drebrin (Shirao, 1995). This can be seen by confocal fluorescence microscopy on freshly dissociated E15 neurons after permeabilizing them and costaining with rhodamine-conjugated phalloidin for F-actin and with an antidrebrin $\mathrm{mAb}$ followed by labeled secondary antibodies for drebrin. The two coincide (Fig. $1 A-D$ ), and they codistribute with the large $\alpha 7$-nAChR clusters visualized by labeling with fluorescently conjugated $\alpha \operatorname{Bgt}$ (Fig. $1 E-H$ ). The clusters have been shown previously to represent $\alpha 7$-nAChRs concentrated on somatic spines (Shoop et al., 1999).

The receptor-rich spines remain for at least $4 \mathrm{hr}$ after dissociated cells are prepared (Fig. $1 E-L$ ). By $8 \mathrm{hr}$, however, the pattern has markedly changed. Both the F-actin labeling and the associated large $\alpha 7$-nAChR clusters are much reduced in number and intensity; numerous microclusters of $\alpha 7-\mathrm{nAChRs}$ are distributed over the cell surface (Fig. $1 M-P$ ). By $12 \mathrm{hr}$ almost no $\alpha 7$-nAChR labeling can be detected, although some F-actin structures can still be distinguished (Fig. $1 Q-T$ ). These images were constructed from vertical stacks of optical sections covering the upper twothirds of the cells; the bottom third was omitted to exclude any contribution from cytoskeletal staining associated with the substratum. In addition, the images were produced under the same conditions to allow direct comparison of signal intensities among panels. It is clear that the residual receptor staining at $12 \mathrm{hr}$ is significantly less even at the remaining sites of F-actin labeling than is seen earlier (e.g., Fig. $1 K, L$ vs $S, T$ ). Either the F-actin structures visible at $12 \mathrm{hr}$ are newly formed and primarily lack $\alpha 7$-nAChRs, or receptor loss from preexisting F-actin structures does not require complete dispersal of the actin cytoskeleton first. Electron microscopy confirmed that the spontaneous dispersal of $\alpha 7$-nAChR clusters and the diminution of associated F-actin in 

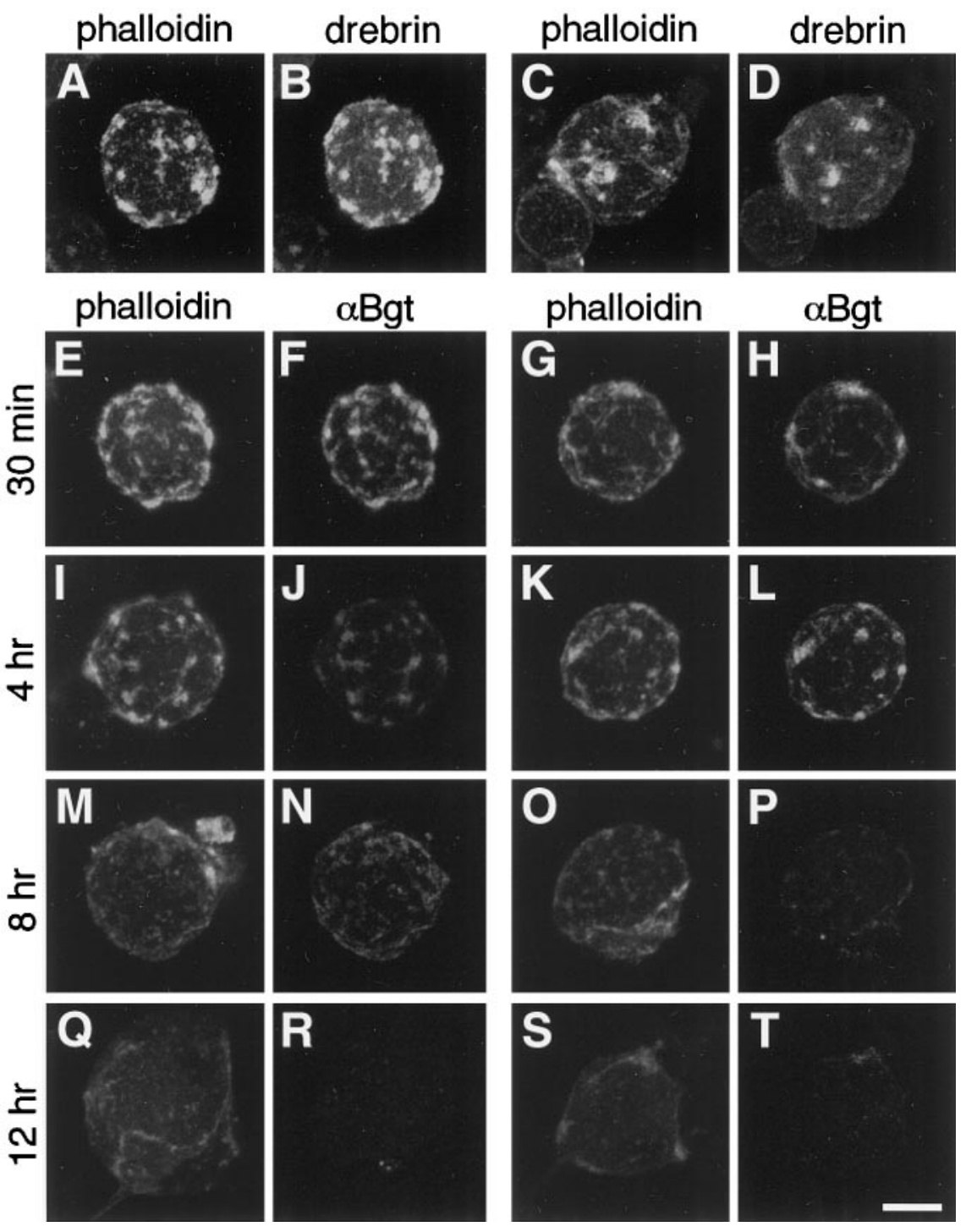

Figure 1. Remodeling of F-actin in culture coincides with the dispersal of surface $\alpha 7$-nAChRs. E15 ciliary ganglion neurons were dissociated, allowed to settle on the substratum, and examined either immediately $(A-H)$ or after $4 \mathrm{hr}(I-L), 8 \mathrm{hr}(M-P)$, or $12 \mathrm{hr}(Q-T)$ for the presence of F-actin using rhodamine-phalloidin (first and third columns) and either drebrin using an anti-drebrin $\mathrm{mAb}$ and Cy3labeled secondary antibody $(B, D)$ or $\alpha 7$-nAChRs using Alexa488- $\alpha \operatorname{Bgt}(F, H, J, L, N, P, R, T)$. Confocal fluorescence images were assembled digitally using optical sections for the upper two-thirds of the cells (thereby omitting signal from the cellular-substratum interface). Each horizontal pair of panels (e.g., $A, B ; C, D)$ represents a single cell doubly stained with the indicated labels. Two examples of each condition (e.g., $A-D$ ) are shown to indicate the variation. The receptors initially codistribute with the F-actin and drebrin comprising somatic spines; the actin filaments slowly redistribute in culture, and the large $\alpha 7$-nAChR clusters are lost. Scale bar, $10 \mu \mathrm{m}$. dissociated neurons correspond to a retraction or loss of the somatic spines (see below).

\section{Disrupting the actin cytoskeleton breaks up the large $\alpha 7-n A C h R$ clusters}

The drug latrunculin A, which destabilizes actin filaments, was used to probe the relationship between F-actin, somatic spines, and $\alpha 7-$ nAChR clusters. E15 neurons were dissociated, allowed to attached to the substratum, and then treated with latrunculin A (4 $\mu \mathrm{g} / \mathrm{ml})$. After $4 \mathrm{hr}$, fluorescence imaging showed that much of the F-actin had been lost and that a dramatic redistribution of $\alpha 7$-nAChRs had occurred on the cell surface (Fig. $2 A, B$ ). The large receptor clusters were gone; instead, numerous faintly labeled microclusters were distributed widely over the surface of the cell. Control cells incubated an equivalent amount of time without latrunculin A displayed the usual large receptor clusters and associated F-actin staining (Fig. 2C,D). Examining the distribution of rhodamine $-\alpha$ Bgt staining on the same cells before and after latrunculin A treatment clearly showed the disappearance of the original large $\alpha 7$-nAChR clusters and the concomitant appearance of numerous microclusters (Fig. 2E,F). Treating cells with $5 \mu \mathrm{M}$ colchicine for $4 \mathrm{hr}$, on the other hand, to disrupt microtubules showed no change in the distribution of $\alpha 7-\mathrm{nAChRs}$ (data not shown).

Electron microscopic analysis was used to examine the effects of latrunculin A on the somatic spines. Surface $\alpha 7$-nAChRs were first labeled with immunogold. On control cells the receptors can be seen heavily concentrated on somatic spines, $\sim 0.2 \mu \mathrm{m}$ in diameter, folded in clumps on the cell surface (Fig. $3 A$ ). Latrunculin A-treated cells, in contrast, had few spine-like structures; those that remained were shrunken in appearance, often being $<60 \mathrm{~nm}$ in diameter (Fig. 3B,C). Immunogold labeling was rarely associated with the spine remnants. Instead, the immunogoldlabeled $\alpha 7$-nAChRs could be found in small patches of variable size distributed nearby on the soma membrane, presumably corresponding to the microclusters of receptors detected with immunofluorescence.

\section{Stabilizing F-actin retains large clusters of $\alpha 7-n A C h R s$ on the cell surface}

Actin filaments can be stabilized by exposure to drugs like jasplikinolide that prevents actin depolymerization (Shurety et al., 1998). When dissociated ciliary ganglion neurons are maintained in culture, the large clusters of $\alpha 7-\mathrm{nAChRs}$ readily apparent on 

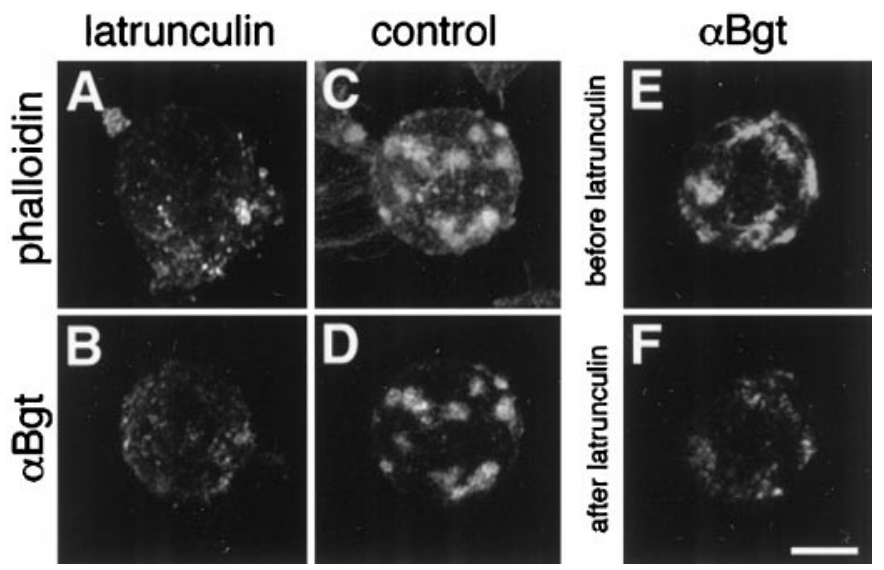

Figure 2. Disrupting the actin cytoskeleton disperses the large $\alpha 7$ nAChR clusters. E15 ciliary neurons were treated with $(A, B, F)$ or without $(C, D$; control) latrunculin A for $4 \mathrm{hr}$ and then labeled for F-actin with rhodamine-phalloidin $(A, C)$ and for $\alpha 7$-nAChRs with Alexa488$\alpha \operatorname{Bgt}(B, D-F)$. Vertical pairs of panels represent the same cell imaged with confocal fluorescence microscopy either immediately $(A, B ; C, D)$ or before and after a $4 \mathrm{hr}$ exposure to latrunculin A $(E, F) . C, D$, The corresponding time control (i.e., the same $4 \mathrm{hr}$ in the absence of latrunculin A) is shown. The latrunculin A treatment caused the loss of F-actin and dispersed the large $\alpha 7$-nAChR clusters into numerous microclusters of receptors distributed over the cell body. Scale bar, $10 \mu \mathrm{m}$.

the cell surface at $4 \mathrm{hr}$ (Fig. $4 A, B)$ are almost completely gone by $12 \mathrm{hr}$ (Fig. 4E,F) and cannot be distinguished at $24 \mathrm{hr}$ (Fig. 4I,J). In the continued presence of jasplikinolide $(4 \mu \mathrm{g} / \mathrm{ml})$, however, the cells retain readily detectable clusters of $\alpha 7-n A C h R s$ on the surface throughout the $24 \mathrm{hr}$ period, although the clusters are somewhat more fragmented and less crisp than those originally present (Fig. 4C,D, G,H,K,L). Drebrin staining was still associated with the receptor clusters in jasplikinolide-treated cells at $24 \mathrm{hr}$, whereas it was much reduced in control cells by this time and no longer associated with receptor clusters (Fig. 4M-P). Thus the jasplikinolide enables the cells to retain spine constituents along with associated $\alpha 7$-nAChRs. The jasplikinolide also prevents neurite formation, presumably because the blockade of actin depolymerization prevents a required reconfiguration of the actin cytoskeleton.

Electron microscopy revealed complex surface structures present on jasplikinolide-treated cells after $24 \mathrm{hr}$ in culture. The structures looked like disorganized and swollen somatic spines. Interestingly, the structures retained $\alpha 7$-nAChRs as evidenced by specific immunogold labeling (Fig. 5). The labeling was too variable to permit meaningful quantification of gold particles per unit length of membrane but was consistent with the patterns inferred from fluorescence microscopy. The results suggest that stabilization of actin filaments under these conditions prevents outright collapse or retraction of the somatic spines; considerable distortion may occur, but the resulting structures still retain $\alpha 7$-nAChRs.

The relationship between F-actin and $\alpha 7$-nAChRs on the cell surface was examined quantitatively using ${ }^{125} \mathrm{I}-\alpha \mathrm{Bgt}$ to measure the number of receptors on the cells in culture. Collapse of the actin filaments by latrunculin $\mathrm{A}$ did not induce a rapid loss of receptors from the cell surface; the number of $\alpha 7-n A C h R s$ on control and latrunculin A-treated cells was indistinguishable at 4 hr (Fig. 6). (These results are not incompatible with the marked differences seen in Fig. 2 for whole-cell fluorescence levels of rhodamine $-\alpha \mathrm{Bgt}$ on control and latrunculin-treated cells at $4 \mathrm{hr}$; diffusely distributed receptors would probably not be visualized if their number per unit of membrane were below some threshold density for detection.) By $24 \mathrm{hr}$ most of the receptors detected by ${ }^{125} \mathrm{I}-\alpha \mathrm{Bgt}$ had been lost in both control and latrunculin-treated cells (Fig. 6). Jasplikinolide had a very different effect. At $24 \mathrm{hr}$, the number of ${ }^{125} \mathrm{I}-\alpha \mathrm{Bgt}$-binding sites remaining on the cells was much larger than that on control cells at $24 \mathrm{hr}$ and, in fact, was equivalent to that present on control cells at $4 \mathrm{hr}$ (Fig. 6). The results indicate that the state of the actin cytoskeleton directly or indirectly determines the complement of $\alpha 7$-nAChRs maintained on the neurons both with respect to number and distribution.

\section{Resistance of $\alpha 7-n A C h R s$ to detergent extraction}

The finding that the actin cytoskeleton influenced the fate of $\alpha 7$-nAChRs on the cell surface indicated a clear linkage of the receptors to cytoskeletal elements. Gentle solubilization of membrane lipid with nonionic detergents can leave such structures intact. This criterion applied to cells in culture has been used previously to demonstrate a cytoskeletal link of glutamate receptors on CNS neurons to actin filaments (Allison et al., 1998).

Evidence consistent with a cytoskeletal linkage for $\alpha 7$ nAChRs was obtained by labeling dissociated ciliary ganglion neurons with rhodamine $-\alpha \mathrm{Bgt}$ in culture and then extracting the cells with $1 \%(\mathrm{v} / \mathrm{v})$ Triton $\mathrm{X}-100$ for $10 \mathrm{~min}$ on ice. Immunofluorescence confocal microscopy of the same cells before and after the extraction showed that most of the $\alpha 7$ nAChRs remained in place (Fig. $7 A-D$ ). A small decrease in signal intensity was apparent, and no dramatic change in distribution occurred. The results suggest that the concentration of $\alpha 7$-nAChRs on somatic spines remains primarily intact after detergent extraction.

As a positive control for the extraction procedure, the fate of $\alpha 3^{*}$-nAChRs on the neurons was monitored. Such receptors are less abundant than $\alpha 7$-nAChRs and can be found in small clusters both on the somatic spines and on the smooth soma membrane (Jacob et al., 1984; Shoop et al., 1999). The receptors can be visualized with immunofluorescence by binding mAb 35 and following with Cy3-labeled secondary antibody. When this is done for neurons treated with the extraction procedure, confocal microscopy shows that virtually all of the surface $\alpha 3^{*}$-nAChRs have been removed (Fig. $7 E, F$ ).

Radiolabeled binding studies were used to quantify the extraction results. Dissociated cells in culture were labeled with ${ }^{125} \mathrm{I}-$ $\alpha$ Bgt for $\alpha 7-n A C h R s$ and with either $\left[{ }^{3} \mathrm{H}\right]$ epibatidine or ${ }^{125} \mathrm{I}$ mAb 35 for $\alpha 3^{*}$-nAChRs and then extracted with $1 \%$ (v/v) Triton $\mathrm{X}-100$ for $10 \mathrm{~min}$ on ice. The procedure removed only $\sim 27 \%$ of the $\alpha 7$-nAChRs from the cell surface, whereas it removed almost all of the $\alpha 3^{*}$-nAChRs (Fig. 8). Most interesting was the effect of latrunculin $\mathrm{A}$ in this case. Although incubation with latrunculin $\mathrm{A}$ for $4 \mathrm{hr}$ removes most of the phalloidin-detectable F-actin (Fig. 2 ), the procedure had almost no effect on the resistance of $\alpha 7$-nAChRs to detergent extraction (Fig. 8). The differential extraction of $\alpha 7$ - versus $\alpha 3^{*}$-nAChRs cannot be ascribed to selective loss of the $\alpha 3^{*}$-nAChR probes in detergent; solid-phase immunoprecipitation assays in which mAb 35 is used to immunotether $\alpha 3^{*}$-nAChRs while $\left[{ }^{3} \mathrm{H}\right]$ epibatidine is used to quantify them are routinely conducted in $0.5-2 \%$ Triton $\mathrm{X}-100$ at room temperature with no difficulty (Conroy and Berg, 1995, 1998) (L. Ogden and D. K. Berg, unpublished results). The results indicate robust molecular interactions tethering $\alpha 7$-nAChRs in the cell in a manner that is resistant to detergent extraction and actin depolymerization. 

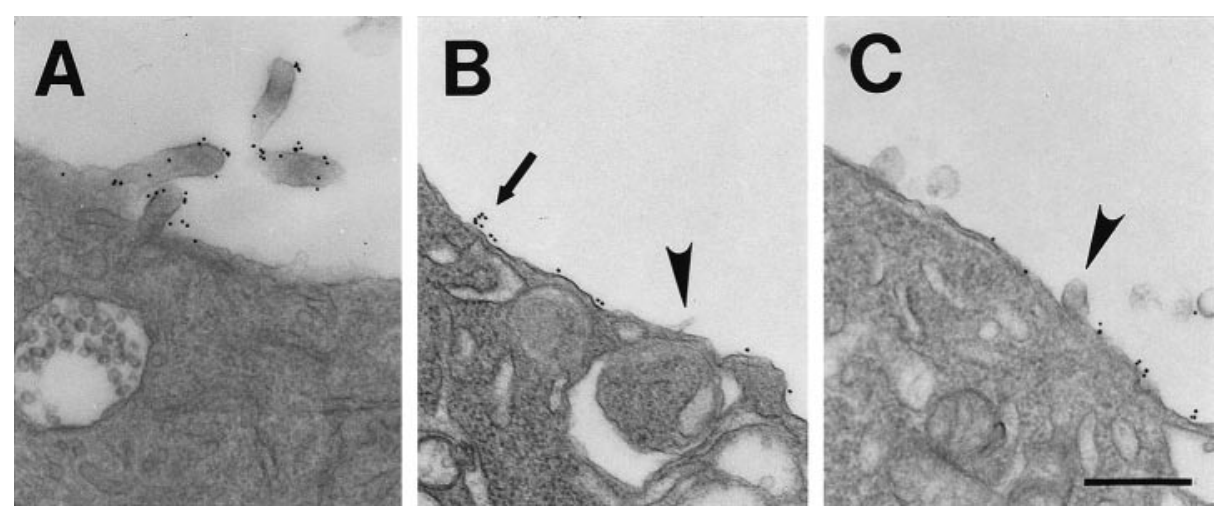

Figure 3. Electron microscopic analysis of immunogold-labeled $\alpha 7$-nAChRs on latrunculin A-treated cells. E15 neurons were incubated $4 \mathrm{hr}$ in culture medium $(A$; control) or in medium containing latrunculin $\mathrm{A}(B, C)$ and then labeled with $10 \mathrm{~nm}$ immunogold for $\alpha 7$-nAChRs and processed for viewing with conventional electron microscopy on thin sections. $A$, On control cells the immunogold-labeled $\alpha 7$-nAChRs can be seen concentrated on somatic spines clumped on the cell surface. $B, C$, After the latrunculin treatment, most of the spines have been lost. The few remaining structures are much reduced in size (arrowheads) and have small clusters of $\alpha 7$-nAChRs ( $a r$ row) nearby on the soma. The example in $C$ was chosen to illustrate the largest spine remnant after latrunculin A treatment. Scale bar, $500 \mathrm{~nm}$.

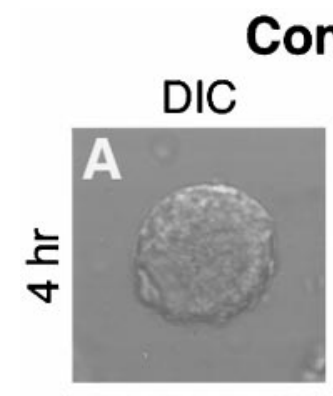

\section{Control}
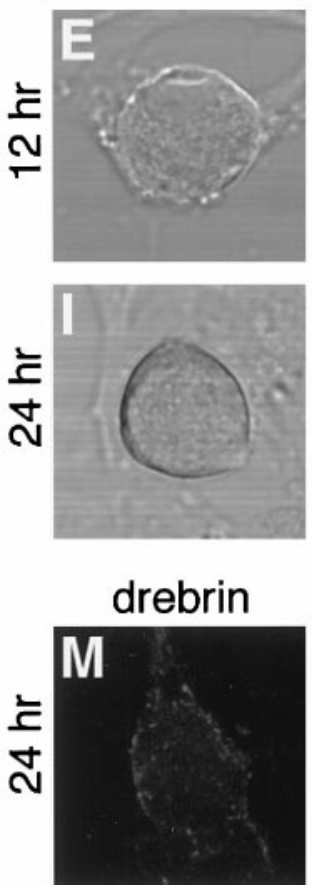
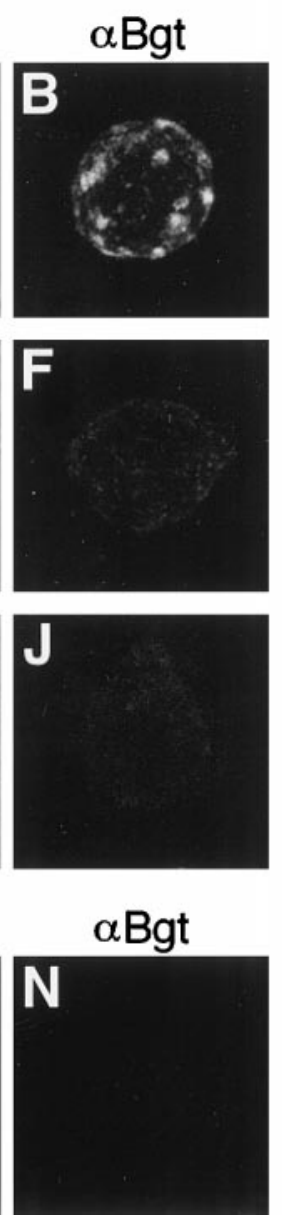

Jasplikinolide
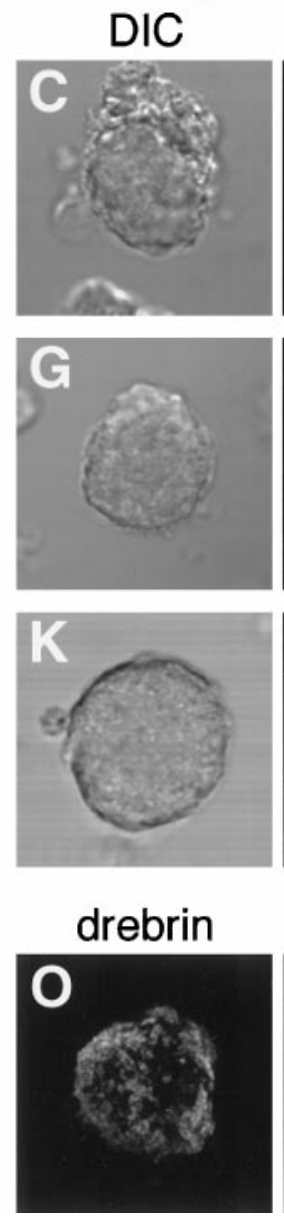
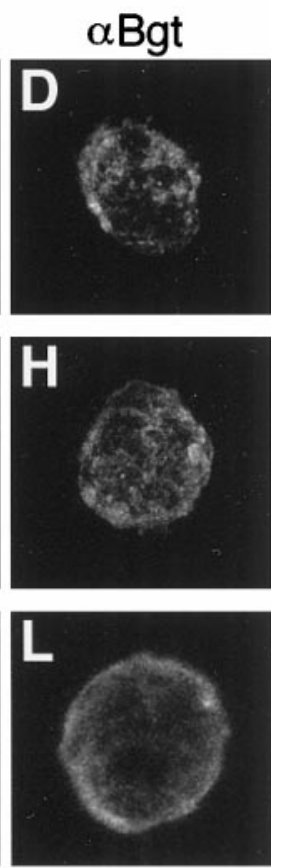

$\alpha \mathrm{Bgt}$

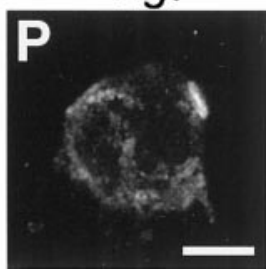

Figure 4. Stabilization of F-actin by jasplikinolide causes $\alpha 7$-nAChRs to be retained in large clusters on the surface of ciliary neurons. Freshly dissociated E15 ciliary ganglion neurons were cultured in the absence (first and second columns) or presence (third and fourth columns) of jasplikinolide for $4 \mathrm{hr}(A-D), 12 \mathrm{hr}$ $(E-H)$, or $24 \mathrm{hr}(I-P)$ and then labeled with rhodamine $-\alpha$ Bgt and viewed with differential interference contrast optics (DIC columns) or confocal fluorescence microscopy ( $\alpha$ Bgt columns). Horizontal pairs of panels (e.g., $A, B ; C, D$ ) represent the same neuron. The bottom row $(M-P)$ shows control $(M, N)$ or jasplikinolide-treated $(O, P)$ neurons labeled for drebrin $(M, O)$ and $\alpha \operatorname{Bgt}(N, P)$ after $24 \mathrm{hr}$. Little, if any, specific $\alpha 7$-nAChR labeling was detectable on the surface of control cells after $24 \mathrm{hr}$ in culture, but clusters of labeled $\alpha 7$-nAChRs remained on the jasplikinolide-treated cells, and the clusters were still associated with drebrin. Scale bar, $10 \mu \mathrm{m}$.

\section{DISCUSSION}

The principal findings reported here are that both the retention of $\alpha 7$-nAChRs on somatic spines and the total number of receptors maintained on the neurons depend on the integrity of the actin cytoskeleton. In addition, molecular interactions resistant to actin depolymerization influence the distribution and membrane stability of $\alpha 7$-nAChRs independent of their location on spines. Such interactions are presumably responsible for the $\alpha 7-\mathrm{nAChR}$ microclusters seen after spine retraction and are specific for the receptors in that they protect $\alpha 7$-nAChRs but not $\alpha 3^{*}$-nAChRs from detergent extraction.

Neurons deploy nAChRs to a variety of locations on the cell surface, depending on the receptor subtypes involved and the functions to be served. Targeting nAChRs to presynaptic terminals enables the receptors to modulate transmitter release (MacDermott et al., 1999), whereas positioning them in postsynaptic membrane increases their contribution to synaptic current (Zhang et al., 1993; Zhang et al., 1996; Roerig et al., 1997; Ullian 
Figure 5. Electron microscopic analysis showing retention of somatic spine-like structures by neurons treated with jasplikinolide. Control $(A)$ and jasplikinolide-treated $(B)$ neurons prepared as described in Figure 4 were immunogold labeled for $\alpha 7$-nAChRs and analyzed by conventional electron microscopy on thin sections. The jasplikinolidetreated cells had swollen spine-like structures decorated with immunogold labeling indicating the presence of $\alpha 7$-nAChRs, whereas control cells were devoid of spines and had little immunogold labeling. Scale bar, $500 \mathrm{~nm}$.
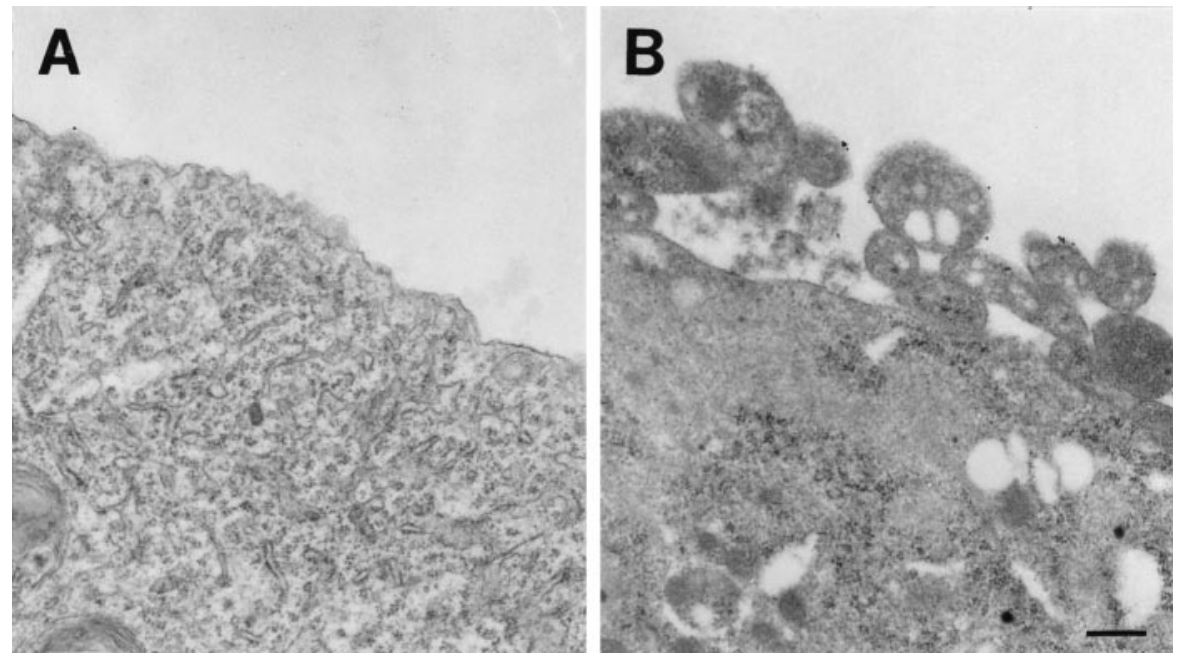

et al., 1997; Frazier et al., 1998; Chang and Berg, 1999; Hefft et al., 1999). Little is known about the molecular mechanisms retaining nAChRs at specific sites on neurons, although recently the intracellular loop between putative transmembrane domains 3 and 4 of the $\alpha 3$ subunit was shown to be instrumental in directing $\alpha 3^{*}$-nAChRs to postsynaptic densities on chick ciliary ganglion neurons in vivo (Williams et al., 1998).

The vertebrate neuromuscular junction represents the beststudied nicotinic synapse. In muscle, nAChRs are held in position by complex machinery involving motoneuron-derived agrin acting, in part, via the receptor tyrosine kinase MuSK to induce rapsyn, a peripheral membrane protein, to cluster nicotinic receptors in the postsynaptic membrane (Sanes and Lichtman, 1999). Neuronal nAChRs are likely to use different elements, if not different mechanisms, to cluster in the plasma membrane and anchor to the cytoskeleton. Although the rapsyn gene is expressed in neurons (Burns et al., 1997; Yang et al., 1997) and can cluster neuronal nAChRs when coexpressed in transfected cells

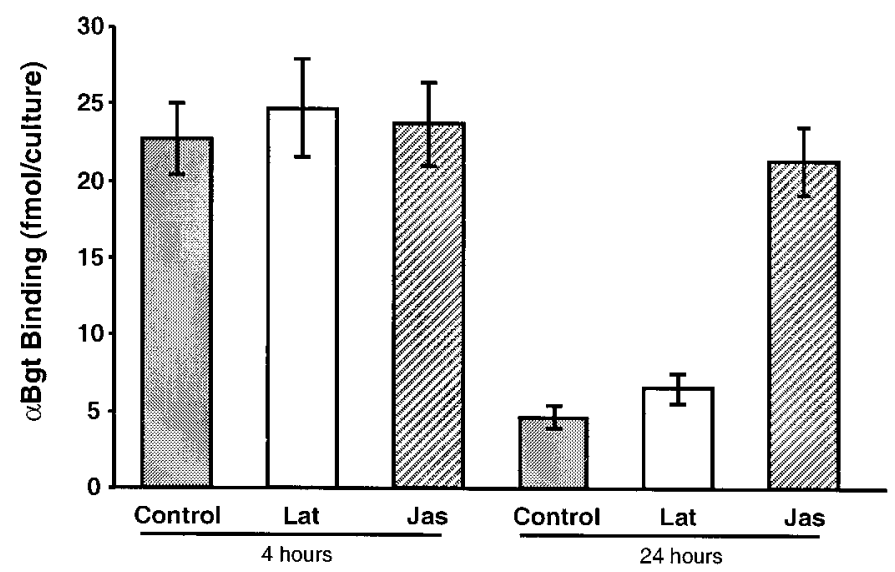

Figure 6. Quantification of $\alpha 7$-nAChRs on neurons after manipulation of the actin cytoskeleton. Freshly dissociated E15 ciliary ganglion neurons were maintained in culture for either 4 or $24 \mathrm{hr}$ in normal medium (Control) or in medium containing either latrunculin A (Lat) or jasplikinolide (Jas). The neurons were then incubated with ${ }^{125} \mathrm{I}-\alpha \mathrm{Bgt}$ to label $\alpha 7$-nAChRs on the cell surface, rinsed, and gamma counted. Values represent the mean \pm SEM of triplicate cultures from each of three experiments. Latrunculin A had no effect on the number of $\alpha 7$-nAChRs present $(p<0.05)$; jasplikinolide completely prevented the loss seen at 24 hr $(p<0.05)$.
(Kassner et al., 1998), rapsyn is not required for clustering of at least some kinds of neuronal nAChRs in vivo (Feng et al., 1998) and is not expressed at sufficient levels to make possible the stoichiometric relationship it has to nAChRs at the neuromuscular junction (Conroy and Berg, 1999).
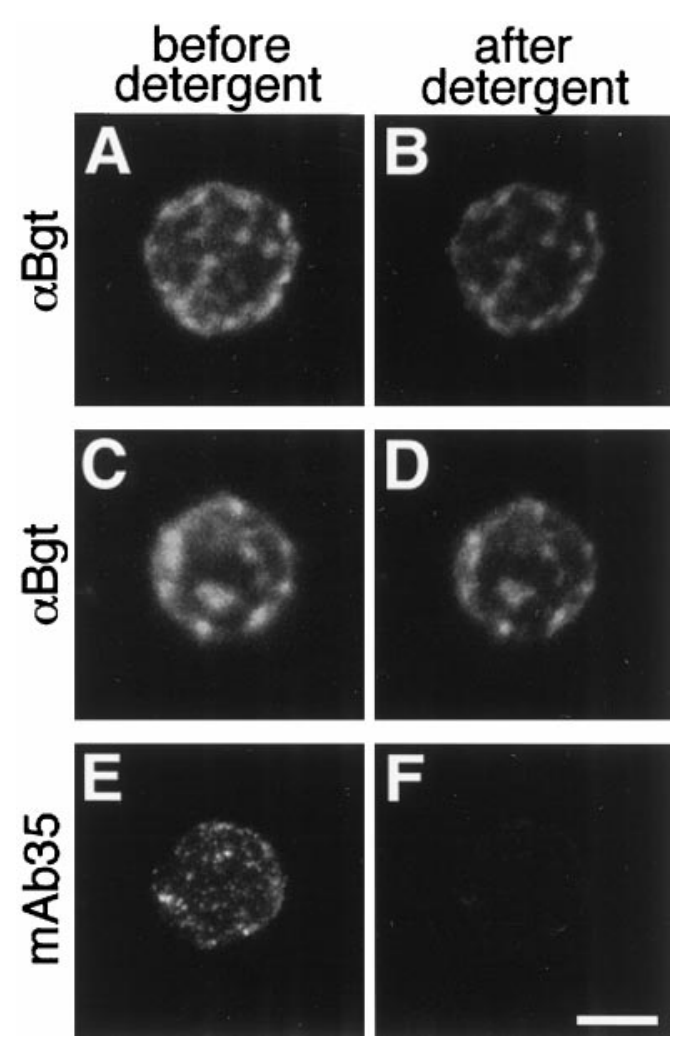

Figure 7. Retention of $\alpha 7$-nAChR clusters after detergent extraction. Dissociated E15 neurons were incubated in culture for $1 \mathrm{hr}$, labeled with either Alexa488- $\alpha$ Bgt for $\alpha 7$-nAChRs $(A-D)$ or mAb 35 followed by Cy3-secondary antibody for $\alpha 3^{*}$-nAChRs $(E, F)$, and then viewed with confocal fluorescence microscopy before $(A, C, E)$ and after $(B, D, F)$ a 10 min extraction with $1 \%$ Triton X-100 on ice. Each horizontal pair of panels shows the same field of view. The extraction with nonionic detergent did not disrupt the large clusters of $\alpha 7$-nAChRs although it removed essentially all of the specific $\alpha 3^{*}$-nAChR labeling. Similar results were obtained when the detergent extraction was performed at room temperature (data not shown). Scale bar, $10 \mu \mathrm{m}$. 


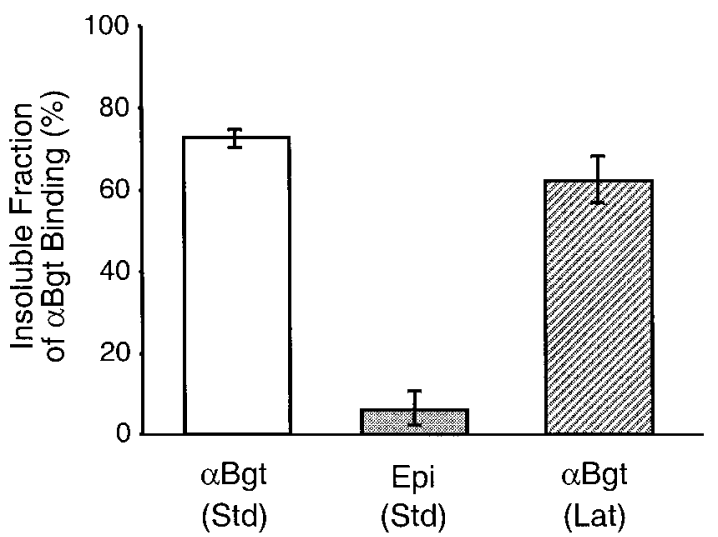

Figure 8. Quantification of nAChRs remaining after detergent extraction. Dissociated E15 neurons maintained in culture for $4 \mathrm{hr}$ were labeled with either ${ }^{125} \mathrm{I}-\alpha \mathrm{Bgt}$ for $\alpha 7$-nAChRs or $\left[{ }^{3} \mathrm{H}\right]$ epibatidine (Epi) for $\alpha 3{ }^{*}$ nAChRs, extracted for 10 min with $1 \%(\mathrm{v} / \mathrm{v})$ Triton $\mathrm{X}-100$, and then counted for retained radioactivity. Values represent the mean \pm SEM of triplicate cultures from each of three experiments and are expressed as a percent of the binding seen in unextracted control cultures. Approximately three-quarters of the $\alpha 7$-nAChRs proved detergent resistant, whereas less than one-tenth of the $\alpha 3^{*}$-nAChRs did so under standard conditions in the absence of drugs $(S t d)$. Dispersal of F-actin by a $4 \mathrm{hr}$ incubation in latrunculin A (Lat) did not significantly alter the proportion of $\alpha 7$-nAChRs resistant to detergent extraction.

More instructive models may come from glutamate receptors on hippocampal neurons. Actin filaments are important for retaining NMDA receptors at synaptic sites on the dendritic spines of pyramidal neurons and AMPA receptors at synaptic sites on the dendritic shafts of GABAergic neurons (Allison et al., 1998). Collapse of the filaments by latrunculin A causes dispersal of the receptors from synaptic sites but does not markedly alter their resistance to solubilization by nonionic detergents. PDZcontaining proteins such as PSD-95, Chapsyn-110, and SAP102 that interact with NMDA receptors (Kornau et al., 1995; Kim et al., 1996; Muller et al., 1996) and tether regulatory components such as SynGAP, nitric oxide synthetase, and citron in the vicinity of the receptors (Brenman et al., 1996; Chen et al., 1998; Kim et al., 1998; Zhang et al., 1999) are thought to induce receptor clustering (Kim et al., 1996; Muller et al., 1996; Hsueh et al., 1997).

The PDZ-containing proteins GRIP1 and 2 and PICK1 may play similar roles for AMPA receptors, whereas Homer may serve this function for some classes of metabotropic glutamate receptors (Brakeman et al., 1997; Dong et al., 1997; Xia et al., 1999). CRIPT binds to PSD-95 and tubulin, suggesting a candidate for tethering receptors to microtubules (Niethammer et al., 1998), and neuroligins bind to PSD-95, suggesting a mechanism for concentrating the complexes at synapses (Irie et al., 1997). Direct evidence of PDZ-containing proteins such as PSD-95 being necessary, however, for receptor clustering in vivo remains elusive (Migaud et al., 1998). Some evidence suggests a direct interaction of NMDA receptors with neurofilaments (Ehlers et al., 1998). NMDA receptors are also linked to actin filaments via $\alpha$-actinin, but this may affect receptor function (Rosenmund and Westbrook, 1993; Wyszynski et al., 1997) more than distribution (Allison et al., 1998). The recent discovery of neuronal acivityregulated pentraxin (Narp) as an extracellular component capable of clustering AMPA receptors adds a new dimension to potential mechanisms controlling receptor distribution on neurons (O’Brien et al., 1999).
Like NMDA receptors, $\alpha 7$-nAChRs on somatic spines are dispersed when $\mathrm{F}$-actin collapses and the spines retract. The large $\alpha 7$-nAChR clusters are never seen in the absence of F-actin costaining, suggesting that spine collapse and receptor dispersal are tightly linked. The reverse, however, sometimes occurs, namely, that some residual F-actin structures, present after 8-12 hr in culture, have little, if any, receptor staining. (Numerous cases of F-actin without receptor could be seen at the cellsubstratum interface at these times, but a possible non-neuronal origin of the F-actin, although unlikely, could not be rigorously excluded, and so these examples were not included here.) The F-actin soma labeling that lacks $\alpha 7$-nAChRs may represent newly formed structures unable to recruit receptor. Alternatively, the collapse of preexisting F-actin and the retraction of somatic spines may not have gone to completion in these cases and yet were still sufficient to allow dispersal of the receptors. Some rearrangement of the spine structure is permissible, however, without losing the associated receptors. Thus jasplikinolide treatment preserves enough of the actin cytoskeleton and associated components to retain the receptors, even though the spines become grossly distorted. The large receptor clusters remain under these conditions but become somewhat more diff use, presumably reflecting the increased surface area occupied by the swollen spines. Spine constituents rather than architecture appear to determine receptor clustering.

The disruption of the actin cytoskeleton does not reduce the $\alpha 7$-nAChR whole-cell response over the short term (Liu and Berg, 1999b). Over the long term, however, the disruption reduces the number of $\alpha 7$-nAChRs maintained on the neurons; both spontaneous and latrunculin A-induced collapse of F-actin and retraction of spines are accompanied by loss of $\alpha 7-n A C h R s$ from the cells, whereas jasplikinolide-induced stabilization of F-actin allows the receptors to be retained. Whole-cell patchclamp recording from control neurons confirms that no detectable $\alpha 7$-nAChR response remains at $24 \mathrm{hr}[<50 \mathrm{pA}$ (Q.-s. Liu and D. K. Berg, unpublished results)]. It is not clear whether the dependence on the integrity of F-actin represents a direct effect of the cytoskeleton on receptor stability or an indirect one in which a reshaping of the cytoskeleton causes global metabolic changes in the cell. In any case, the delay between F-actin collapse and $\alpha 7$-nAChR loss from the surface suggests that intervening steps are rate-limiting for receptor removal.

Another similarity between NMDA receptors and $\alpha 7$-nAChRs with respect to membrane localization is that both are resistant to extraction with nonionic detergents and remain so after latrunculin A-induced depolymerization of F-actin in the cells. The most likely explanation is that cytoskeletal elements in addition to F-actin play a role in determining the distribution of $\alpha 7-\mathrm{nAChRs}$, although other kinds of molecular interactions could also account for the resistance of the receptors to detergent extraction. These same cytoskeletal elements or molecular interactions may be responsible for the $\alpha 7$-nAChR microclusters seen on the cell body after latrunculin A-induced spine collapse. Interestingly, detergent insolubility does not extend to $\alpha 3^{*}$-nAChRs under these conditions. Some $\alpha 3^{*}$-nAChRs are concentrated in postsynaptic densities (Jacob et al., 1984; Loring and Zigmond, 1987; Williams et al., 1998) and are, therefore, likely to be resistant to detergent extraction (Kennedy, 1997), but these must be relatively minor in number. Most appear to be located on somatic spines, as are $\alpha 7$-nAChRs (Jacob and Berg, 1983; Loring et al., 1985; Wilson Horch and Sargent, 1995; Shoop et al., 1999). Apparently the cytoskeletal elements or molecular events responsible for the 
detergent insolubility of $\alpha 7$-nAChRs are not themselves a prerequisite for the clustering of receptors on spines.

One difference between the receptor-laden somatic spines examined here on ciliary ganglion neurons and the previously described dendritic spines in hippocampal cultures is that the latter appear to be much more stable (Allison et al., 1998). The systems differ with respect to cell type, species, and type of spine, but perhaps the most salient difference is that the hippocampal dendritic spines develop well after the neurons have adapted to cell culture and extended neurites. The ciliary ganglion neurons examined here had been freshly dissociated, transferred to cell culture, and examined over the next few hours. Cellular adaptations to the in vitro environment, e.g., attachment to the substratum and regeneration of processes, may induce major rearrangement of the actin cytoskeleton during this time. The rearrangement could destabilize preexisting actin-dependent structures such as the somatic spines.

The results presented here indicating cytoskeletal links to $\alpha 7$-nAChRs suggest the existence of scaffold-like proteins responsible both for coalescing the receptors into microclusters and for tethering the receptors or the microclusters on the spines. Such proteins may also be responsible for anchoring regulatory components in the immediate vicinity of the receptors. Examples of regulatory components known to exert an actin-dependent influence on $\alpha 7$-nAChR function in the neurons include $\mathrm{CaM}$ kinase II and calcineurin (Liu and Berg, 1999b). A future challenge will be the identification of putative scaffold proteins and elucidation of what they contribute to nicotinic synaptic structure and signaling.

\section{REFERENCES}

Allison DW, Gelfand VI, Spector I, Craig AM (1998) Role of actin in anchoring postsynaptic receptors in cultured hippocampal neurons: differential attachment of NMDA versus AMPA receptors. J Neurosci 18:2423-2436.

Anand R, Peng X, Lindstrom J (1993) Homomeric and native $\alpha 7$ acetylcholine receptors exhibit remarkably similar but non-identical pharmacological properties, suggesting that the native receptor is a heteromeric protein complex. FEBS Lett 327:241-246.

Bertrand D, Galzi JL, Devillers-Thiery A, Bertrand S, Changeux J-P (1993) Mutations at two distinct sites within the channel domain M2 alter calcium permeability of neuronal $\alpha 7$ nicotinic receptor. Proc Natl Acad Sci USA 90:6971-6975.

Brakeman PR, Lanahan AA, O'Brien R, Roche K, Barnes CA, Huganir RL, Worley PF (1997) Homer: a protein that selectively binds metabotropic glutamate receptors. Nature 386:284-288.

Brenman JE, Chao DS, Gee SH, McGee AW, Craven SE, Santillano DR, Wu Z, Huang F, Xia H, Peters MF, Froehner SC, Bredt DS (1996) Interaction of nitric oxide synthase with the postsynaptic density protein PSD-95 and $\alpha 1$-syntrophin mediated by PDZ domains. Cell 84:757-767.

Burns AL, Benson D, Howard MJ, Margiotta JF (1997) Chick ciliary ganglion neurons contain transcripts coding for acetylcholine receptorassociated protein at synapses (rapsyn). J Neurosci 17:5016-5026.

Chang K, Berg DK (1999) Dependence of circuit function on nicotinic acetylcholine receptors containing $\alpha 7$ subunits. J Neurosci 19:3701-3710.

Chen H-J, Rojas-Soto M, Oguni A, Kennedy MB (1998) A synaptic Ras-GTPase activating protein (p135 SynGAP) inhibited by CaM kinase II. Neuron 20:895-904.

Choi DW (1992) Excitotoxic cell death. J Neurobiol 23:1261-1276.

Conroy WG, Berg DK (1995) Neurons can maintain multiple classes of nicotinic acetylcholine receptors distinguished by different subunit compositions. J Biol Chem 270:4424-4431.

Conroy WG, Berg DK (1998) Nicotinic receptor subtypes in the developing chick brain: appearance of a species containing the $\alpha 4, \beta 2$, and $\alpha 5$ gene products. Mol Pharmacol 53:392-401.

Conroy WG, Berg DK (1999) Rapsyn variants in ciliary ganglia and their possible effects on clustering of nicotinic receptors. J Neurochem 73:1399-1408.

Couturier S, Bertrand D, Matter J-M, Hernandez M-C, Bertrand S, Millar N, Valera S, Barkas T, Ballivet M (1990) A neuronal nicotinic acetylcholine receptor subunit $(\alpha 7)$ is developmentally regulated and forms a homo-oligomeric channel blocked by $\alpha$-Btx. Neuron 5:847-856.

Dong H, O'Brien RJ, Fung ET, Lanahan AA, Worley PF, Huganir RL (1997) GRIP: a synaptic PDZ domain-containing protein that interacts with AMPA receptors. Nature 386:279-384.

Ehlers MD, Fung ET, O'Brien RJ, Huganir RL (1998) Splice variantspecific interaction of the NMDA receptor subunit NR1 with neuronal intermediate filaments. J Neurosci 18:720-730.

Engert F, Bonhoeffer T (1997) Synapse specificity of long-term potentiation breaks down at short distances. Nature 388:279-284.

Feng G, Steinbach JH, Sanes JR (1998) Rapsyn clusters neuronal acetylcholine receptors but is inessential for formation of an interneuronal cholinergic synapse. J Neurosci 18:4166-4176.

Frazier CJ, Buhler AV, Weiner JL, Dunwiddie TV (1998) Synaptic potentials mediated via $\alpha$-bungarotoxin-sensitive nicotinic acetylcholine receptors in rat hippocampal interneurons. J Neurosci 18:8228-8235.

Harris KM, Kater SB (1994) Dendritic spines: cellular specializations imparting both stability and flexibility to synaptic function. Annu Rev Neurosci 17:341-371.

Hefft S, Hulo S, Bertrand D, Muller D (1999) Synaptic transmission at nicotinic acetylcholine receptors in rat hippocampal organotypic cultures and slices. J Physiol (Lond) 510:709-716.

Hsueh Y-P, Kim E, Sheng M (1997) Disulfide-linked head-to-head multimerization of the mechanism of ion channel clustering by PSD-95. Neuron 18:803-814.

Irie M, Hata Y, Takeuchi M, Iohtchenko K, Toyoda A, Hirao K, Takai Y, Rosahl TW, Sudhof TC (1997) Binding of neuroligins to PSD-95. Science 277:1511-1515.

Jacob MH, Berg DK (1983) The ultrastructural localization of $\alpha$-bungarotoxin binding sites in relation to synapses on chick ciliary ganglion neurons. J Neurosci 3:260-271.

Jacob MH, Berg DK, Lindstrom JM (1984) Shared antigenic determinant between the Electrophorus acetylcholine receptor and a synaptic component on chicken ciliary ganglion neurons. Proc Natl Acad Sci USA 81:3223-3227.

Kassner PD, Conroy WG, Berg DK (1998) Organizing effects of rapsyn on neuronal nicotinic acetylcholine receptors. Mol Cell Neurosci 10:258-270.

Kennedy MB (1997) The postsynaptic density at glutamatergic synapses. Trends Neurosci 20:264-268.

Kim E, Cho K-O, Rothschild A, Sheng M (1996) Heteromultimerization and NMDA receptor-clustering activity of chapsyn-110, a member of the PSD-95 family of proteins. Neuron 17:103-113.

Kim JH, Liao D, Lau L-F, Huganir RL (1998) SynGAP: a synaptic RasGAP that associates with the PSD-95/SAP90 protein family. Neuron 20:683-691.

Kornau H-C, Schenker LT, Kennedy MB, Seeburg PH (1995) Domain interaction between NMDA receptor subunits and the postsynaptic density protein PSD-95. Science 269:1737-1740.

Krupp JJ, Vissel B, Thomas CG, Heinemann SF, Westbrook GL (1999) Interactions of calmodulin and $\alpha$-actinin with the NR1 subunit modulate $\mathrm{Ca}^{2+}$-dependent inactivation of NMDA receptors. J Neurosci 19:1165-1178.

Liu Q-s, Berg DK (1999a) Extracellular calcium regulates the responses of both $\alpha 3$ - and $\alpha 7$-containing nicotinic receptors on chick ciliary ganglion neurons. J Neurophysiol 82:1124-1132.

Liu Q-S, Berg DK (1999b) Actin filaments and the opposing actions of $\mathrm{CaM}$ kinase II and calcineurin in regulating $\alpha 7$-containing nicotinic receptors on chick ciliary ganglion neurons. J Neurosci 19:10280-10288.

Loring RH, Zigmond RE (1987) Ultrastructural distribution of ${ }^{125} \mathrm{I}$ toxin $\mathrm{F}$ binding sites on chick ciliary neurons: synaptic localization of a toxin that blocks ganglionic nicotinic receptors. J Neurosci 7:2153-2162.

Loring RH, Dahm LM, Zigmond RE (1985) Localization of $\alpha$-bungarotoxin binding sites in the ciliary ganglion of the embryonic chick: an autoradiographic study at the light and electron microscopic level. Neuroscience 14:645-660.

MacDermott AB, Role LW, Siegelbaum SA (1999) Presynaptic iono- 
tropic receptors and the control of transmitter release. Annu Rev Neurobiol 22:443-485.

Mainen ZF, Malinow R, Svoboda K (1999) Synaptic calcium transients in single spines indicate that NMDA receptors are not saturated. Nature 399:151-155.

Malenka RC, Nicoll RA (1999) Long-term potentiation-a decade of progress? Science 285:1870-1874.

Migaud M, Charlesworth P, Dempster M, Webster LC, Watabe AM, Makhinson M, He Y, Ramsay MF, Morris RGM, Morrison JH, O’Dell TJ, Grant SGN (1998) Enhanced long-term potentiation and impaired learning in mice with mutant postsynaptic density-95 protein. Nature 396:433-439.

Muller BM, Kistner U, Kindler S, Chung WJ, Kuhlendahl S, Fenster SD, Lau L-F, Veh RW, Huganir RL, Gundelfinger ED, Garner CC (1996) SAP102, a novel postsynaptic protein that interacts with NMDA receptor complexes in vivo. Neuron 17:255-265.

Muller W, Connor JA (1991) Dendritic spines as individual neuronal compartments for synaptic $\mathrm{Ca}^{2+}$ responses. Nature 354:73-76.

Niethammer M, Valtschanoff JG, Kapoor TM, Allison DW, Weinberg RJ, Craig AM, Sheng M (1998) CRIPT, a novel postsynaptic protein that binds to the third PDZ domain of PSD-95/SAP90. Neuron 20:693-707.

Nishi R, Berg DK (1981) Two components from eye tissue that differentially stimulate the growth and development of ciliary ganglion neurons in cell culture. J Neurosci 1:505-513.

O’Brien RJ, Xu D, Petralia RS, Huganir RL, Worley P (1999) Synaptic clustering of AMPA receptors by the extracellular immediate-early gene product Narp. Neuron 23:309-323.

Phillips WD, Noakes PG, Roberds SL, Campbell KP, Merlie JP (1993) Clustering and immobilization of acetylcholine receptors by the $43-\mathrm{kD}$ protein: a possible role for dystrophin-related protein. J Cell Biol 123:729-740.

Roerig B, Nelson DA, Katz LC (1997) Fast synaptic signaling by nicotinic acetylcholine and serotonin $5-\mathrm{HT}_{3}$ receptors in developing visual cortex. J Neurosci 17:8353-8362.

Rosenmund R, Westbrook GL (1993) Calcium-induced actin depolymerization reduces NMDA channel activity. Neuron 10:805-814.

Sanes JR, Lichtman JW (1999) Development of the vertebrate neuromuscular junction. Annu Rev Neurosci 22:389-442.

Schoepfer R, Conroy WG, Whiting P, Gore M, Lindstrom J (1990) Brain $\alpha$-bungarotoxin binding protein cDNAs and mAbs reveal subtypes of this branch of the ligand-gated ion channel gene superfamily. Neuron $5: 35-48$.

Seguela P, Wadiche J, Dineley-Miller K, Dani JA, Patrick JW (1993) Molecular cloning, functional properties, and distribution of rat brain $\alpha 7$ : a nicotinic cation channel highly permeable to calcium. J Neurosci 13:596-604.

Shirao T (1995) The role of microfilament-associated proteins, drebrins, in brain morphogenesis: a review. J Biochem 117:231-236.

Shoop RD, Martone ME, Yamada N, Ellisman MH, Berg DK (1999) Neuronal acetylcholine receptors with $\alpha 7$ subunits are concentrated on somatic spines for synaptic signaling in embryonic chick ciliary ganglia. J Neurosci 19:692-704.

Shurety W, Stewart NL, Stow J (1998) Fluid-phase markers in the basolateral endocytic pathway accumulate in response to the actin assemblypromoting drug jasplikinolide. Mol Biol Cell 9:957-975.

Ullian EM, McIntosh JM, Sargent PB (1997) Rapid synaptic transmission in the avian CG is mediated by two distinct classes of nicotinic receptors. J Neurosci 17:7210-7219.

Williams BM, Tamburni MK, Schwartz Levey M, Bertrand S, Bertrand D, Jacob MH (1998) The long internal loop of the $\alpha 3$ subunit targets nAChRs to subdomains within individual synapses on neurons in vivo. Nat Neurosci 1:557-562.

Wilson Horch HL, Sargent PB (1995) Perisynaptic surface distribution of multiple classes of nicotinic acetylcholine receptors on neurons in the chicken ciliary ganglion. J Neurosci 15:7778-7795.

Wyszynski M, Lin J, Rao A, Nigh E, Beggs AH, Craig AM, Sheng M (1997) Competitive binding of alpha-actinin and calmodulin to the NMDA receptor. Nature 385:439-442.

Xia J, Zhang X, Staudinger J, Huganir RL (1999) Clustering of AMPA receptors by the synaptic PDZ domain containing protein PICK1. Neuron 22:179-187.

Yang S-H, Armson PF, Cha J, Phillips WD (1997) Clustering of $\mathrm{GABA}_{\mathrm{A}}$ receptors by rapsyn $/ 43 \mathrm{kD}$ protein in vitro. Mol Cell Neurosci $8: 430-438$.

Yuste R, Denk W (1995) Dendritic spines as basic functional units of neuronal integration. Nature 375:682-684.

Zhang M, Wang YT, Vyas DM, Neuman RA, Bieger D (1993) Nicotinic cholinoceptor-mediated excitatory postsynaptic potentials in rat nucleus ambiguus. Exp Brain Res 96:83-88.

Zhang W, Vazquez L, Apperson M, Kennedy MB (1999) Citron binds to PSD-95 at glutamatergic synapses on inhibitory neurons in the hippocampus. J Neurosci 19:96-108.

Zhang Z-w, Vijayaraghavan S, Berg DK (1994) Neuronal acetylcholine receptors that bind $\alpha$-bungarotoxin with high affinity function as ligandgated ion channels. Neuron 12:167-177.

Zhang Z-w, Coggan JS, Berg DK (1996) Synaptic currents generated by neuronal acetylcholine receptors sensitive to $\alpha$-bungarotoxin. Neuron 17:1231-1240. 